\title{
Sherlock Holmes inside a textbook. Archaeology of a teacher training text from the early $19^{\text {th }}$ century
}

\author{
Sherlock Holmes entra no coração de um livro de texto. Arqueologia de um \\ manual para professores do início do Século XIX na Itália
}

Sherlock Holmes entra en el corazón de un libro de texto. Arqueología de un manual para los maestros de principios del siglo XIX en Italia

\begin{abstract}
Sherlock Holmes entra nel cuore di un libro di testo. Archeologia di un manuale per maestri del primo Ottocento in Italia
\end{abstract}

\author{
MiRELla D’AsCENZO ${ }^{1}$
}

\begin{abstract}
In Italy, since the late 1990s there have been many research works on school and educational publishing, interlacing with the current fields of investigation common in Europe and beyond. Numerous earlier studies offered historians deeper knowledge of school publishing, in terms of the production and distribution of school textbooks between the $19^{\text {th }}$ and $20^{\text {th }}$ centuries, school publishers, legislation on school textbooks and the ideologies and values underlying school text. However, very few studies have investigated the aspects specifically linked to the history of the subject teaching methods in these books, and their everyday practical use and application by the teachers in the class. This essay analyses a teacher training manual to identify the words and expressions that offer clues and signs of the underlying methodological and teaching traditions, revealing the pedagogic and educational knowledge used for teacher education. The work analyses a teacher training manual, like a young Sherlock Holmes searching with a magnifying glass for clues among single words or sentences that can reveal the archeologically stratified teaching traditions of the early $19^{\text {th }}$ century.
\end{abstract}

Keywords: Primary school. Textbooks. Teacher training. Material school culture.

\footnotetext{
1 Dottore di ricerca in Pedagogia presso l'Università degli Studi di Bologna. Professoressa associata confermata. Dipartimento di Scienze Dell'Educazione "Giovanni Maria Bertin". Università di Bologna (Italy). Email: mirella.dascenzo@unibo.it
} 
Resumo: Pesquisas sobre a história da editoria pedagógica e acadêmica conheceram um fecundo período de estudos, a partir do final dos anos de 1990, na Itália, entrelaçando-se com uma linha comum de investigação generalizada em nível europeu e internacional. Os numerosos estudos já realizados nos permitiram alcançar um conhecimento mais profundo da editoria educacional, ao nível de produção editorial e da circulação de manuais escolares entre o Oitocentos e Novecentos, sobre os editores para a escola, sobre disposições normativas relacionadas ao livro escolar e sobre aspectos ideológicos e valorativos subjacentes aos livros-texto. Todavía poco estudiados son los aspectos más relacionados a la historia de las metodologías y de la enseñanza disciplinar presentes en los libros destinados al aula y el uso real, la práctica concreta del libro en el aula en la mediación desarrollada por los docentes. En este artículo se ofrece un análisis de un libro escolar al recoger palabras y frases reveladoras de "indicios" y "acechados" de tradiciones metodológicas y didácticas subyacentes, capaces de revelar la circulación del saber pedagógico y didáctico destinado a la formación de los docentes. En particular, se analizará un manual para profesores al modo de Sherlock Holmes, a través de una lente de detective, en busca de vestigios en torno a palabras aisladas o frases reveladoras de tradiciones didácticas arqueológicamente estratificadas en la primera mitad del siglo XIX.

Palavras-chave: Escola Elementar. Livro-texto. Formação de Professores. Cultura Material Escolar.

Resumen: Investigaciones sobre la historia de la editorial pedagógica y académica conocieron un fecundo período de estudios, a partir de finales de los años 1990, en Italia, entrelazándose con una línea común de investigación generalizada a nivel europeo e internacional. Los numerosos estudios ya realizados nos permitieron alcanzar un conocimiento más profundo de la editorial educativa, al nivel de producción editorial y de circulación de manuales escolares entre los Ochocientos y Novecientos, sobre los editores para la escuela, sobre disposiciones normativas relacionadas al libro escolar y sobre aspectos ideológicos y valorativos subyacentes a los libros-texto. En el caso de los alumnos de la escuela primaria, los alumnos de la escuela primaria y secundaria de la escuela primaria y secundaria. En este artículo se ofrece un análisis de un libro escolar al recoger palabras y frases reveladoras de "indicios" y "acechados" de tradiciones metodológicas y didácticas subyacentes, capaces de revelar la circulación del saber pedagógico y didáctico destinado a la formación de los docentes. En particular, se analizará un manual para profesores al modo de Sherlock Holmes, a través de una lente de detective, en busca de vestigios en torno a palabras aisladas o frases reveladoras de tradiciones didácticas arqueológicamente estratificadas en la primera mitad del siglo XIX.

Palabras clave: Escuela elemental; libro de texto; Formación de profesores; Cultura material de la escuela.

Sommario: Le ricerche sulla storia dell'editoria pedagogica e scolastica hanno conosciuto una feconda stagione di studi dalla fine degli anni Novanta in poi in Italia, intrecciando il coevo filone di indagine diffuso a livello europeo e internazionale. Le numerose ricerche già svolte hanno permesso di giungere ad una conoscenza più approfondita dell'editoria scolastica, a livello di produzione editoriale e di circolazione dei manuali scolastici tra Ottocento e Novecento, sugli editori per la scuola, sulle disposizioni normative legate al libro scolastico e sugli aspetti ideologici e valoriali sottesi ai libri di testo. Ancora poco studiati appaiono gli aspetti più squisitamente legati alla storia delle metodologie e delle didattiche disciplinari presenti nei libri nonché l'uso reale, la pratica concreta del libro in classe nella mediazione didattica svolta dai docenti. In questo contributo si offre l'analisi di un manuale scolastico per coglierne parole e frasi rivelatrici di 'indizi' e spie' di tradizioni metodologiche e didattiche sottese, capaci di rivelare la circolazione del sapere pedagogico e didattico destinato alla formazione dei docenti. Si analizzerà in particolare un manuale per maestri come novelli Sherlock Holmes, alla ricerca di tracce con la lente del detective sulle singole parole o frasi rivelatrici tradizioni didattiche archeologicamente stratificate nella prima metà dell'Ottocento.

Parole chiave: Scuola Elementare; Libri di Testo; Formazione dei Maestri; Cultura materiale della scuola. 


\section{Introduction}

Some years ago, Professor A. Escolano Benito entitled an interesting research essay to the famous investigator Sherlock Holmes in order to support his historical and educational investigation and his studies of heritage. He evoked the implicative methods of Carlo Ginzburg and the semiotics of Umberto Eco, based on the careful reading of the words and images Foucault used in his works to broaden the archaeology of knowledge, the expression of power relationships and social, cultural and political power in societies (ESCOLANO BENITO, 2010; GINZBURG, 1986; 2006; FOUCAULT 1966). Here I would like to apply the same investigative and archaeological method in the analysis of an Italian teacher training manual from the first half of the $19^{\text {th }}$ century, in this case focusing the attention on the different layers of sedimentation of the various teaching traditions emerging from some clues in the book, to understand the teaching culture and circulation of ideas and practices in teacher training rather than a social, historical or sociological reading.

The clues offered by some words allow us to dig progressively deeper, investigating the methodological and educational stratifications of a textbook deposited over time, clearly within a broader reading of the context of the book itself, in other words the recipients, the internal rhythm of the contents and the political and cultural model the authors aimed to disseminate.

Thus, this kind of analysis aims to focus the attention of school historians from the study of publishing policies and the values and models of conduct of the ruling classes presented to students in school textbooks (CHIOSSO 2013; ASCENZI, 2013; SANI, 2013; D'ASCENZO, 2013) to general teaching and individual subjects, with a view to identifying a different historical investigation method, paying attention to the single words, the nuances of meaning, all the possible clues and signs which, like authentic "spies", reveal to the historian-detective that complex system of subject teaching skills or the topics themselves covered by the book.

But what is this book? Why is it worth studying? It is a small teacher training manual entitled Istruzioni di Maurizio Serra al maestro della scuola normale del villaggio di Bunnanaro in Sardegna. Published in 1825 before the Unification of Italy, it was composed of 104 pages and was used to train primary school teachers, generally the curate of a village school.

The author, Maurizio Serra, graduated very young in theology. He was a teacher at the Regia Scuola di Sassari (Sardinia) and then became parish priest of Bunnanaro in 1802, where he opened a school. The text was published in the period of regulations issued by the Kingdom of Piedmont and Sardinia before the Unification of Italy concerning public education (MASALA, 1912; ALBERTI, 1998; PRUNERI, 2011; ROGGERO, 1981 and 1982; BIANCHINI, 2008) and was specifically addressed to parish priests, who were called on to assist the State in educating the population, in an alliance between the throne and church. Indeed:

to obey to his sacred ministry, (the priest) is bound to enlighten the people, acting as a guide mainly in all that concerns morality and religion. He would be too guilty if he did not take pleasure in the 
thought of the ensuing improvements, if he did not seek to cooperate with all his means to the prosperity of an Institution, of which, due to his office and by order of the King, the priest is guardian, support and guide. (SERRA, 1825, p. 29)

The future teacher-priest should have been the "reformer of customs of the general public, meritorious of the Church and of the State, indeed the Guardian Angel, who indicates the right path in order not to stray early on from the path to Heaven" (Ibidem, p.4). Driven by these civil and pastoral beliefs, Serra decided to use:

the spare time my pastoral Ministry luckily left me to offer you a brief summary of the most suitable maxims for you, the place and people you have to educate, and to train you as I would like, and hope that you become, a teacher most worthy of the appreciation of the Government, the gratitude of the Public and blessing of God (Ibidem, p.5)

thus feeling the need to produce "concise instructions" (Ibidem, p. 7) for the new curate and future teacher. Having defined the context, aims of the book and its recipients, reading in more detail we find a first clue that reveals the interesting underlying teaching method. Serra stated that his inspiration came from personal experience and some books:

sent to me by a worthy ecclesiast, once tutor of the seminarians in the Diocese, and a man who burns with the desire to bring all forms of knowledge and advantages to his fellow countrymen. (Ibidem, p.5)

Who was the tutor Serra referred to? Priest Antonio Manunta, theologian of the University of Sassari, interesting figure of pre-Unitarian Sardinia chosen by King Carlo Felice to write the 'Regolamento delle Scuole Normali', (Regulation of the "Scuole Normali"). Manunta travelled to Milan, experiencing the educational and pedagogical reforms brought to Austrian Lombardy, as can be seen in some sources of the time as well as more recent studies:

he went in Milan at his own expense to learn the teaching method, attending the Teacher Training School led by Professor Francesco Cherubini, with whom he corresponded constantly until the death of this bright and famous philosopher. (PRUNERI, 2011, p. 208).

Manunta had attended the Caponomale teacher training school in Milan, a school managed from 1820 to 1848 by Francesco Cherubuni, the translator of teacher training methodology works written by Joseph Peitl, the director of Normal School of Vienna and student of the Austrian pedagogue Eduard Milde, one of the leading names in Austrian pedagogy in the late $18^{\text {th }}$ century (POLENGHI, 2003; 2012; 2016). "Normal" school refers to both teacher training schools and primary schools inspired by the method started in Austrian Lombardy in the late $18^{\text {th }}$ century by the enlightened despotism of Maria Theresa of Austria, 
organised in terms of teaching and education by Ignazio Felbiger and Francesco Soave. The normal method marked a very important reform: aiming to fight the illiteracy of the population, it replaced individual teaching by tutors or the teaching in Latin in colleges. It was a simultaneous teaching method oriented to a group of students by a single teacher, standing on a platform behind the teacher's desk, and thus the holder of knowledge and the guide of the learning process.

The teacher was not only required to be fully familiar with the cultural contents of the discipline, but also the ability to present them, dividing the subject analytically and gradually into parts, according to a predetermined rhythm of work, aiming to avoid wasting of time. In this way:

children occupied in useful tasks (...) have no time to get bored, nor lose themselves and escape to impudent trifles, from which it is difficult to tear them away when they are not busy. (SOAVE, 1805, pp.8-9)

It is well known that the normal method made the research into new teaching tools crucial, such as the introduction of the slate blackboard, visible to everyone at the same time, as well as specific books for every subject and specifically for training teachers. Texts by the Austrian pedagogists Feilbiger, Milde, Peitl were translated by Italian academics involved in the education reforms in Lombardy and Veneto, including Francesco Soave and Francesco Cherubini. Cherubini in particular translated the text Förderungen an Lehrer written by Joseph Peitl in 1821 (SOAVE, 1821; POLENGHI, 2004; 2012; 2016). Moreover, in the monarchy of Maria Theresa of Austria and her son Giuseppe, Francesco Soave was responsible for the birth of the Caponormale teacher training school, writing textbooks for all school subjects, which thus became the primary source of subsequent Italian educational texts, also thanks to the continuation of Francesco Cherubini and the school reforms of Piedmont (SOAVE, 1771; 1786; 1801; 1806; 1807; 1808; BIANCHINI, 2010).

From Serra's quote given above, we may legitimately suppose that Antonio Manunta himself had sent texts about the normal method used in Lombardy before 1824, thus contributing to the educational and pedagogical renewal in Sardinia. Indeed, these texts were the primary source for the drafting of Serra's book, so admired by authorities that it was presented as a mandatory reference for the schools and teachers of Sardinia in the 1824 Regolamento per le scuole normali (PRUNERI, 2011, p. 231).

For this reason, the following year the Istruzioni were printed by the Royal Printing Agency of Turin, and Maurizio Serra was promoted to priest of Sassari, then head of the Normal Schools Commission and, finally, member of the Board of Educational Governors ("Magistrato degli Studi") in Sassari.

\section{Searching for educational stratifications}

After an introduction clearly addressed to his student, Maurizio Serra wrote that the normal school should 
allow the teacher to rightly judge the natural aptitudes of his students in the various professions they will enter, and allow the students to work well and proficiently in any job, to which they can dedicate themselves to following their teacher's advice and their parents' approval. (SERRA, 1825, p.9)

This means that the teacher had the responsibility for choosing the job for those who would not continue their studies. Thus, topics were about religion, morality, agriculture and arithmetic, in addition to the need to learn to read and write. Indeed, "it is appropriate that the teacher starts teaching the alphabet" (Ibidem). The "concise instructions" were divided in sectors corresponding to these subjects, and organised in detail for each one following the specific system of gradualness (from the known to the unknown, from the simple to the complex, from the easy to the difficult). It also provided an indication of the relevant methodological and educational procedures and instruments, from school materials to text books and models of texts that could be used during the lessons.

Looking at the book's table of contents, we can see how most of the chapters covered language learning, followed by the religious topics, arithmetic, moral and civic education, and lastly an anthological part aiming on one hand to provide the legislative references and on the other to provide working materials for the class teachers, including the most commonly used moral instructions, short texts, and private writing models taken from different sources, as explained in the last page of the book by the author, who calls them 'notes'. The book's pillar centred around language learning, but the unitary nature of the book was clear: the author aimed on one hand to produce a small "compendium of method", and on the other hand wished to offer recipients a kind of complete "handbook" of useful examples, enriched by a series of recommendations for teachers on how to manage educational relations with students and the social relations in the classroom.

As stated above, the most consistent portion was devoted to language teaching (Teaching the alphabet; Spelling and Hyphenation; Teaching to read; The choice of reading books, Reading methods, Calligraphy), followed by arithmetics (Arithmetics, divided into Mental arithmetics, Arithmetics in numbers - with a part on the four operations), then orthography (Orthography in general; Orthography in particular). Then religion (Religious education and Civil Education) followed by Some advice for the Teacher, while an Appendix, some Maxims, From Religious texts, Pious love and Models ended the volume, providing further suggestions on the teachers' conduct in and outside the classroom. As Serra stated that he was inspired by some Lombard works sent by Manunta, the first, superficial layer of the 'educational stratification' of his Istruzioni is somewhat clear. There is a direct link with both Francesco Soave's Compendio del metodo normale written by, and Cherubini's translation of Förderungen an Lehrer by Joseph Peitl, where the author stated that he had added some elements of the Peitl's larger work Methodenbuch and of the Compendio del Soave; he also stated that he had introduced 'modifications required by the huge differences between the German and the Italian language' (CHERUBINI, 1821, p. 2). Like Soave and Cherubini, Serra also kept the teaching of reading separate from writing, and indeed the simultaneous teaching of reading and writing was to take hold in school, with great difficulties in its concrete 
application, later in the $19^{\text {th }}$ century. The teaching methods of "the alphabet", "spelling and hyphenation" and "teaching to read" remained separate and were followed by those of teaching to write, understood traditionally as the learning of calligraphy and precise textual styles, codified in the Models in the form of letters and other useful texts for everyday life.

As far as learning the letters of the alphabet was concerned, the Sardinian teacher distanced himself from Soave's Compendio, which presented the letters in an order based on their graphic appearance and their gradual and subsequent modifications, thus conceived merely as a preparatory exercise for writing. Soave instead followed Peitl and Cherubini's Manuale of 1821 , which suggested starting by teaching the vowels ${ }^{2}$, however thereafter presenting the letters based on their graphic appearance.

In addition to presenting the vowels before the consonants, Serra also distanced himself from the "Lombard" method of teaching first the capital and then the minuscule letters, contrary to Soave and Cherubini. Moreover, Serra clearly and unequivocally wrote that the teacher should pay attention to the pronunciation of consonants, following their pure sound and not the name of the letters themselves, again distancing himself from the traditional alphabetic method and the ambiguities of Soave and Cherubini's system.

Indeed, the teacher:

shall pronounce the consonants and make the students pronounce them with their pure sound, so that the sound of letters like B', C', D', etcetera be clearly heard. He shall above all avoid saying 'effe', 'elle', 'emme', 'essa' for f, m, n, s. (SERRA, p. 10)

This unequivocal statement represents a new clue of another, deeper educational stratification that emerges from the Istruzioni, one much earlier than the Lombard method: I refer to that used in the Piarist Schools of Giuseppe Calasanzio and the Scolopi, which had been running schools for the poor across the island for many years. Dating back to the $17^{\text {th }}$ century, Serra was familiar with the classical Scolopian tradition, and was consequently aware of the use of phonic reading of the letters of the alphabet, which had been common since the age of humanism but which had not really become an actual phonic method for learning to read, introduced in Germany much later by Ickelsamer, Jacotot and Stephani (BUISSON, 1882; RACCUGLIA, 1893; MARTINAZZOLI， CREDARO， GASPARINI， 1984; GENOVESI, 1987; ROGGERO, 2000).

Phonic reading was introduced into Scolopian traditions at least in the $18^{\text {th }}$ century (BOCHICCHIO, 1995, p. 43), when, having to adapt the teaching of reading to the poor and lower social classes had attempted different methods from the traditional alphabet-syllabic method used since ancient times, progressively introducing phonic reading using the vernacular and introducing the study of calligraphy and the abacus. It is likely that Serra was inspired by the Calasanzian tradition for phonic reading, and this emerges from another clue

\footnotetext{
2 "Education starts from teaching the vowels. The consonants, which can be easily pronounced, come after; the composed or double letters then follow. Thereafter, or immediately after the vowels, diphthongs and triphthongs", in Manuale dei maestri elementari o sia compendio dei metodi d'insegnamento e d'educazione prescritti per elementari nel Regno Lombardo-Veneto, cit., p. 1.
} 
found in his Istruzioni, where the author recommends the use of a chart written with letters "made from punched copper", to hang in the class:

on the school wall, a chart will hang written in big letters made from punched copper, or in other ways: this will bring the advantage that it will stick in the eyes and the minds of the students, following the instructions given by the teacher while pointing with his stick. (SERRA, p.10)

This was such a huge difference, considering the method that Calasanzio described in his Breve relazione, a teaching text written in 1610 . He said:

as regards the letters, starting from the youngest pupils, the school should only host those who learn the Holy Cross and how to pronounce the single letters. And because there are usually 60, or even 70 students, one teacher alone would not be able to teach to such a large number. Thus, the chart is hung on the wall, written in big letters, and the teacher points to each of the letters with his stick two or three times. In this way, children have to repeat the letters several times, and they start to learn to read. On the other hand, the teacher easily identifies the brilliant and bright students. Pupils who know how to read the single letters must look at another chart on the wall, where equally big syllables are shown, like ba, be, ab and eb, and other simple words that can be easily read. The pupils able to read those words can be promoted to the next class. (SANI, p. 562)

Continuing to read Serra's manual, another educational clue appears. The slate blackboard would

lessen the teacher's fatigue, ensuring greater results for the pupils when the smooth, slate blackboard is delivered to the school. (SERRA, p. 11)

Introduced by the normal method and in Europe in the later $18^{\text {th }}$ century (BUISSON, 1882; AMORIGGI, DESIDERI, 1990), Francesco Soave described the blackboard in his Compendio:

every school has a blackboard, two and a quarter arms in length, one and a half arms in height. It is made of a light wood, so that it can be easily moved; it is painted black on each side, and one side is marked with lines in a different colour, spaced about two inches apart; the paint is such that it can be written on easily with white clay or chalk, and all that is written can be removed with a damp sponge, without leaving any trace. The board is placed on a support, similar to a 
painter's easel, and dowels are placed in the legs to raise or lower the height of the board, just as painters do when they are at work. (...) The blackboard is positioned in a place where all the pupils are able to see it easily. The teacher writes on the blackboard with the chalk in a square figure, so that every pupil can see what he or she has to learn written on the board. (SOAVE, 1805, pp. 11-12)

In Cherubini's Manual, the blackboard is considered an essential tool:

the teacher must produce on the blackboard all the minuscule letters in the order they are presented one after the other in the primer; he must re-write them in large, precise capital letters, and make sure that the pupils learn them. (CHERUBINI, p. 1)

Serra demonstrated his knowledge of the slate blackboard, and even suggested that other future teachers of Sardinia use it as a teaching tool:

many pupils will be told to spell the same words on the blackboard, and others to hyphenate them, in order to save time and effort. One of them will spell the words out loud, while others do it whispering, following the word spelled and pointed at by the stick with their eye; thus also for the purpose of hyphenating. (SERRA, 1825, p. 17)

Designed for teacher training, the Manuale reveals important elements linked to the learning contents, the values and models of perfect conduct the teachers should offer to new generations, obviously linked to the Catholic model. The part called 'Massime' indicated the Christian values of forgiveness, truth, respect for parents and authority, co-responsibility of human beings, the fight against vanity and against the temptation of unproductive laziness (that prelude to the destitution of the poor). These all represent an explicit form of values and models of conduct for the pupils, also included in Soave's Abbecedario. The Massime were to be followed by books overcoming traditional religious readings:

it does not seem possible to me to continue following the old methods of primary schools, methods that embarrass pupils with reading or the Latin office of the Holy Virgin Mary, or of the Given, or of the Elements of the Latin language, and other similar books. (Ibidem, p. 22)

suggesting "the second and the third volumes of the beautiful children's readings proposed by Professor Anselmi, along with the two first volumes of Holy History: such volumes are sold loose in Turin at a very modest price" (Ibidem, pp. 22-23). The name Anselmi represents another clue referring to yet another teaching tradition, this one closer to Serra in both time and space. Giuseppe Anselmi was a supporter of the liberal scholastic reforms in Piedmont in the early $19^{\text {th }}$ century. During the Restoration, he drafted a reform to replace the old spelling 
and Latin learning schools with a more articulated school system (ANSELMI, 1818; CHIOSSO, 1994; ROGGERO, 2000; BIANCHINI, 2008). Indeed, Anselmi had developed a number of school textbooks and started one of the first educational periodicals in Piedmont, entitled " $L$ 'Educatore di famiglia". Maurizio Serra made explicit reference to these texts by Anselmi and in particular to the volumes on Holy History, the Grammatica and other children's books and "his journal l'Educatore f." (Ibidem, p. 104). Serra quoted Anselmi again with reference to the teaching of orthography, particularly concerning double consonants by referring to the rules of the "third section of Professor Anselmi's Italian Grammar" later illustrated by Serra (SERRA, p. 50). Orthography occupied a huge part of Serra's Instructions, as can be seen from some traces in the text:

finally, when the pupils start to spell and hyphenate the letters, the aims of a good teacher must turn to teaching them doggedly to write in the proper manner, otherwise called orthography. (SERRA, p. 41)

The Sardinian teacher offered precise indications for teaching, with a well-structured internal method: individual writing under dictation in quinterni ${ }^{3}$, another transcriptions on loose sheets, individual then collective corrections read out loud and a second collective dictation with the transcription of the rules learned in another quinterno, for consultation as needed.

As regards orthography, Serra mentions Bartoli on the issue of double consonants. Bartoli thought that "some words are written as they please, with single or double letters, by the authors of the best times" (SERRA, p. 48). This man was probably a famous authority of the time, which would explain why Serra did not feel the need to indicate his first name or even initial. But who was he? Probably, in the context, he was Daniello Bartoli, a Jesuit who lived in the $17^{\text {th }}$ century but who was often mentioned by the greatest experts of language in $19^{\text {th }}$ century Italy (ASOR ROSA, 1964; BALLERINI, 1985). Serra was clearly familiar with Bartoli's works, directly or indirectly, indeed perhaps even via Anselmi, and thus demonstrated a wealth depth of updated educational and teaching knowledge.

\section{Spies on teaching writing and arithmetic}

Continuing with our reading of Serra's manual for Sardinian teachers, we enter the sphere of learning and teaching writing. To be done after learning to read, the author left much room for learning to write, and indeed stated that:

once pupils have learned to read sufficiently, the teacher shall start to teach them how to write. (SERRA, p. 25)

Here he maintained the continuity between tradition and the normal method, which proposed that letters be learned by their shape, presented analytically and gradually, seeking to understand the differences in letters according to the lines used (straight, curved, slanting).

\footnotetext{
${ }^{3}$ A sort of modern "notebook" composed of five sheets folded in two and placed one inside the other. Its purpose was to arrange loose sheets which could be ordered according to need.
} 
As regards the procedures, he invited the teacher to teach the use of calligraphy tools, so that the pupils would learn to see the lines on the blank page, like "fine sand", if only to save paper. The reference ring to 'fine sand' offers yet another clue of a more remote level of educational stratification in the text, which is the knowledge of the teaching practices of the mutual teaching method, promoted in England by Samuel Bell and Joseph Lancaster in the late $18^{\text {th }}$ century and spread firstly in France by the Societé pour l'instruction elementaire, and later in Switzerland with Pestalozzi and eventually in Italy, in particular in Lombardy, thanks to Federico Confalonieri in the newspaper "Il Conciliatore", Tuscany, the Kingdom of Naples and Piedmont. This method was well known for saving time and money: it was a rational system used to teach more than three hundred pupils at a time in the same place, divided into eight classes of equal level for each subject. A single teacher directed them according to their "prior knowledge". Monitors assisted the teachers in the classrooms, chosen from among the best students of each class. Their task was to repeat the lesson to their group of no more than twenty pupils sitting in a line of desks. The "savings" could easily be seen also in the tools used, including the 'fine sand', set in a hole in the desk, on which the children drew both letters, again presented according to their similarities in shape following the calligraphic teaching method, and numbers for the arithmetic teaching. The alphabet was however learned in an innovative manner, both reading and writing at the same time; spelling was based on a phonic and syllabic system, as indicated by Lancaster who stated:

behind the usual method, the art of writing is completely separated from reading and spelling. In the new system, spelling and writing are linked in the lessons, and are combined with reading; the same is done for writing and arithmetic. (LANCASTER, 1816, p. 15)

The pupils were arranged in a semicircle before the charts or "wall paintings" containing synoptic tables of syllables and words, guided by the monitors chosen from among the most brilliant students. The reference to "fine sand" in Serra's Istruzioni leads us to believe that he was familiar with mutual teaching. Indeed "for this purpose, seeking to avoid the useless soiling of paper right from the outset, the teacher will get the pupils accustomed to writing the letters on the blackboard, if there is one, or on fine sand" (SERRA, p. 25).

In fact this is only a hypothesis that cannot be fully verified, but it is likely. Fine sand was adopted in teaching by the Ancient Jews in the $17^{\text {th }}$ century (MANTELLINO, 1909, $\mathrm{p}$. 154), inherited informally in the modern age from calligraphy teaching practices in the classic age , so it is possible that Serra made explicit reference to this specific teaching tool inspired by practices even earlier than the mutual teaching method, perhaps also due to his own personal experience as the parish teacher in his village.

A large section of Serra's Istruzioni was dedicated to arithmetic, inspired by the above-mentioned Cherubini's Manuale. Cherubini wrote:

the study starts by teaching the pupils how to count. They have to count their fingers, their fellow pupils, the benches, the books, the pens, the windows and other things that can be easily seen and counted from 2 to 5, 7, 10 and more, increasing the units and repeating the things previously counted at the same time. (CHERUBINI, p. 25) 
Similarly, Serra wrote that they must be taught to:

count $1,2,3,4,5,6,7,8,9,10$ on their fingers; then to count their fellow pupils, the books, the pens and other touchable things. (SERRA, p. 30)

The examples used for learning to add were also very similar. While Cherubini stated:

a father gives his son two pears, then another one, and then two more. How many pears will the son have? (SERRA, p. 30)

the Sardinian teacher said:

a father gave his son two pears for breakfast, three for lunch, one for dinner and two during the night. How many pears did he give his son? (SERRA, p. 30)

However, Serra did not suggest, as Soave did in his Compendio and Peitl and Cherubini did in their Manuale, the use of the abacus, thinking that oral or mental counting was a better method to adopt. He insisted on the techniques of mutual teaching, which, as reported in Buisson's Dictionnaire some decades later, "il invente, pour apprendre le calcul aux enfants, une methode particulière" (BUISSON, 1882, p. 1483).

The attention on the practicality of arithmetic and the capacity for oral counting, as a crucial part of schools for the people, perhaps referred to the knowledge and success of the Scuola della Mendicità Istruita in Turin, referred to explicitly by Maurizio Serra in the part dedicated to arithmetic (if however offering an example of teaching activity that had little to do with mutual practices but rather more generally simultaneous methods):

a pupil is called to the numbers dictated by the teacher on the blackboard, and all the school will look at him. The teacher will call for silence and attention by hitting the cane on the desk. Two more hits will instruct another pupil to say the calculation aloud. One more hit and the pupil must fall silent and the next pupil will go on, and so on, to increase and encourage the attention of the listeners. This method can be also adopted in reading the tables, avoiding the waste of time, boredom and effort. (SERRA, pp. 22-23)

On the other hand, Lancaster wrote in his British System of Education:

a pupil must proceed spontaneously, without any previous knowledge of the example and without the support of the monitor. If he errs, the next pupil must immediately correct him. (LANCASTER, 1816, p. 67) 
The absence of the abacus as a traditional tool for teaching arithmetic appears strange. It was essential in the Scolopian Pious Schools and normal schools of Lombardy, as Soave noted in his works. The teacher should:

above all, when moving on to multiplication, ensure that they learn the abacus or the multiplication table by heart. For this purpose, the teacher shall make use of a large abacus to help the pupils in their practice. (SOAVE, 1805, p. 73)

Perhaps the experience gained as a village teacher led him to eliminate it from teaching practice, preferring the mutual teaching techniques that were closely linked to the faster and less cumbersome oral counting (BUISSON, 1882; AMBRISI, DESIDERI, 1989). The mutual teaching methods were not however widespread, and Serra never referred to the possible use of monitors - typical of mutual teaching - for classroom organisation, management and discipline, thus remaining fully bound to the normal method.

\section{In conclusion}

The analysis of this teaching manual reveals not only the values and the models of conduct passed on to the pupils, but also the rich heritage of teaching traditions to be found in text books. In particular, this analysis reveals a number of important elements to the historian of education. On one hand, the presence of methodological teaching traditions, deposited in different layers of history which constitute the 'slow rhythm of History', the 'long duration' of Braudelian memory. And on the other, it reveals Serra's personal interpretation of old and new teaching traditions through the filter of his personal experience and educational sensitivity developed 'in the field'. This is a common element shared by teachers of all places and all times, and constitutes that 'empirical culture of school' (ESCOLANO BENITO, 2016), which is a key aspect in the development of the teaching profession.

Lastly, conducted with evidence-based, archeologic method, this kind of analysis can contribute not only to illuminating the specific geographical contest in which such a teacher training manual is written and published (D'ASCENZO, 2016), but also to offering a more detailed reconstruction of the comparative history of school culture and education (JULIA, 1995), and particularly general teaching methods and specific teaching methods applied to school subjects (CHERVEL, 1998; BELHOSTE, 2005; VIÑAO FRAGO, 2006; BIANCHINI, 2009; POLENGHI, 2014; 2016). In doing so, education historians can contribute to a more aware training of future teachers.

\section{References}

A Sua eccellenza il Conte e Commendatore Prospero Balbo, omaggio di una orazione latina e Idea d'una correzione al sistema di pubblica istruzione, scritta già d'ordine superiore per l'anno 1814-1818. Torino: Stamperia reale, 1818.

ALBERTI, Laura. Alfabetizzazione popolare e riforme scolastiche in Sardegna. Le istruzioni di Maurizio Serra per i maestri delle scuole normali (1824). Sacer, n.5, pp. 99-129, 1998. 
AMBRISI, Emilio; DESIDERI, Ippolito. Abaco. In: LAENG, Mauro (ed.). Enciclopedia pedagogica. Brescia: La Scuola, 1989, vol. I, pp. 1-8.

AMORIGGI, Rosa; DESIDERI, Ippolito. Lavagna. In: LAENG, Mauro (ed.). Enciclopedia pedagogica. Brescia: La Scuola, 1990, vol. IV, pp. 6583-6589.

ASCENZI, Anna. La ricerca sulla manualistica scolastica in Italia: nuovi orientamenti storiografici e prospettive di ricerca. In: MEDA, Juri; BADANELLI RUBIO, Ana Maria. La historia de la cultura escolar en Italia y en Espana: balance y perspectivas. Macerata: EUM, 2013, pp. 119-138.

ASOR ROSA, Alberto. Bartoli Daniello. In: Dizionario biografico degli italiani. Roma: Istituto della Enciclopedia italiana, 1964, vol. 6, p. 566.

AUSENDA, Giovanni. La pedagogia calasanziana. In: BRAIDO, Pietro. Esperienze di pedagogia cristiana nella storia, vol. I, secc. XIV-XVII. Roma: LAS, 1981, pp. 325-396.

BALLERINI, Roberto. Alla ricerca di un nuovo metodo: il corso grammaticale nel secolo dei Lumi. In: BRIZZI, Gian Paolo (ed.). Il catechismo e la grammatica, I: Istituzioni e controllo sociale nell'area emiliano romagnola nel Settecento. Bologna: Il Mulino, 1985.

BECCHI, Egle; FERRARI Monica (edd.). Formare alle professioni. Sacerdoti, principi, educatori. Milano: Angeli, 2009.

BELHOSTE, Bruno. Culture scolaire et histoire des disciplines. Annali di storia dell'educazione e delle istituzioni scolastiche, 12, 2005, pp. 213-223.

BETTI, Carmen. Arte educativa e scienza pedagogica nella manualistica magistrale. In: CHIOSSO, Giorgio (ed.). TESEO '900: editori scolastico-educativi del primo Novecento. Milano: Bibliografica, 2008, pp. CXXV-CXLIII.

BIANCHINI, Paolo. Educare all'obbedienza. Pedagogia e politica in Piemonte tra Antico Regime e Restaurazione. Torino: SEI, 2008.

BIANCHINI, Paolo. Le origini delle materie. Discipline, programmi e manuali scolastici in Italia. Torino: SEI, 2010.

BOCHICCHIO, Franco. L'organizzazione degli studi nel collegio degli Scolopi. In ID. Democratizzazione della scuola italiana. Momenti e problemi. Bologna: CLUEB, 1995.

BUISSON, Ferdinand. Voci Abaque, Abécédaire, Ardoises Ecriture, Aritmétique, Calcul, Calcul intuitie, Calcul mental, Ecriture-lecture. In: ID. Dictionnaire de pédagogie et d'instruction primaire, $\mathrm{I}^{\circ}$ partie, tome premier. Paris: Librairie Hachette et C., 1882, pp. 1; 23; 109-111; 114-118; pp. 314-316; pp. 316-317; p. 317; 798-801; 801-803.

BUISSON, Ferdinand. Voci Lancaster, Lecture. In: ID. Dictionnaire de pédagogie et d'instruction primaire publié sous la direction de F. Buisson, $\mathrm{I}^{\circ}$ partie, tome second. Paris: Librairie Hachette et C., 1882, pp. 1483; 1534-1551. 
CHERUBINI, Francesco. Manuale dei maestri elementari o sia compendio dei metodi d'insegnamento e d'educazione prescritti per le scuole elementari nel Regno LombardoVeneto. Milano: Imperial Regia Stamperia, 1821.

CHERVEL, André. L'histoire de disciplines scolaires. Réflexions su un domaine de recerche. Histoire de l'education, 38, 1998, pp. 59-119.

CHIOSSO, Giorgio (ed.). La stampa pedagogica e scolastica in Italia (1820-1943). Brescia: La Scuola, 1997, pp. 262.

CHIOSSO, Giorgio. La manualistica scolastica in Italia: tematiche, metodologie, orientamenti. In MEDA, Juri; BADANELLI RUBIO, Ana Maria. La historia de la cultura escolar en Italia y en Espana: balance y perspectivas. Macerata: EUM, 2013, pp. 47-59.

COLLI VIGNARELLI, Francesco. Gli Scolopi in Sardegna. Cagliari: Gasperini, 1982.

D'ASCENZO, Mirella. Col libro in mano. Maestri, editoria e vita scolastica tra Otto e Novecento. Torino: SEI, 2013.

D'ASCENZO, Mirella. Linee di ricerca della storiografia scolastica in Italia: la storia locale. Espacio, Tiempo y Educación, 3(1), 2016, p. 249-72. https://doi.org/10.14516/ete.2016.003.001.13

DE VIVO, Francesco. Giuseppe Calasanzio e le scuole pie. In: AA.VV. Nuove questioni di storia della pedagogia. Vol. 1. Brescia: La Scuola, 1977, pp. 709-735.

ESCOLANO BENITO, Agustin. La cultura empirica della scuola. Esperienza, memoria, archeologia. Ferrara: Volta La Carta, 2016.

ESCOLANO BENITO, Agustin. Sherlock Holmes goes to school. Etnohistory of the school and educational heritage. History of Education \& Children's Literature, V, 2, 2010, pp. 17-32.

FOUCAULT, Michel. Archeologia del sapere, Milan: Rizzoli, 1971.

FOUCAULT, Michel. Le parole e le cose. Un'archeologia delle scienze umane, Milan: BUR, 2004 [1966];

GASPARINI, Duilio. Da Ickelsamer a Comenio. Il metodo fonico e il primo abbecedario illustrato. Roma: Armando, 1984.

GENOVESI, Giovanni. Leggere e scrivere, che fatica! Apprendimento della lettura e della scrittura nei primi quaranta anni unitari. LA SCRITTURA. Fare scuola, n. 6, nov. 1987, pp. 51-70.

GINZBURG, Carlo. Il filo e le tracce. Vero, falso, finto. Milano: Feltrinelli, 2006.

GINZBURG, Carlo. Miti, emblemi, spie. Morfologia e storia. Torino: Einaudi, 1986.

LANCASTER, Joseph. Sistema inglese di istruzione ossia raccolta de' miglioramenti e delle invenzioni poste in pratica nelle scuole reali d'Inghilterra di G. Lancaster e Piano di educazione pe' fanciulli poveri secondo i metodi combinati del dottor Bell e del predetto sig. Lancaster. Milano: Sonzogno, 1816 [ ${ }^{\circ}$ ed. 1797]. 
LUCCHI, Piero. La prima istruzione. Idee, metodi, libri. In: BRIZZI, Gian Paolo (ed.). Il catechismo e la grammatica. I. Istituzioni e controllo sociale nell'area emiliano romagnola nel Settecento. Bologna: Il Mulino, 1985, p. 25-81

LUCCHI, Piero. La Santacroce, il Salterio, il Babuino. Libri per imparare a leggere nel primo secolo della stampa. Quaderni storici, n. 38, 1978, pp. 593-639.

MANTELLINO, Giacomo. La scuola primaria e secondaria in Piemonte e particolarmente in Carmagnola. Carmagnola: Rossetti, 1909.

MARTINAZZOLI, Antonio; CREDARO, Luigi. Dizionario illustrato di pedagogia, voci Metodi per insegnare a leggere, Leggere, Scrittura, Sillabario fonico-acustico, sillabario grafico ortofonico. Milano: Vallardi, rispettivamente alle pp. 667-675; 448-456; 453-466; 527-530.

MASALA, Giovanni. La Sardegna e la Scuola del Popolo. Sassari: Tipografia e Legatoria G. Gallizzi e C., 1912.

PANCERA, Carlo. Maestri e istruzione popolare in Lombardia nel periodo preunitario. I Problemi della Pedagogia, 2000, n.4-6, pp.299-337.

PETTINATI, Nino. Vincenzo Troya e la riforma scolastica in Piemonte. Torino: Paravia, 1896.

POLENGHI, Simonetta. Catholic enlightenment for children. Teaching religion to children in the Hasburg empire from Joseph II to the Restauration. Historia y memoria de la educación, 4, 2016, pp. 49-84.

POLENGHI, Simonetta. La formazione dei maestri nel Lombardo-Veneto: le traduzioni di Francesco Cherubini dei testi di J. Peitl (1820-1821), Le carte e gli uomini. Storia della cultura e delle istituzioni. Studi in onore di Nicola Raponi. Milano: Vita e Pensiero, 2004, pp. 153-173.

POLENGHI, Simonetta. La formazione dei maestri nella Lombardia austriaca. In: ID. (ed.). La scuola degli Asburgo. Pedagogia e formazione degli insegnanti tra il Danubio e il Po (1773-1918). Torino: SEI, 2012, pp. 45-89.

POLENGHI, Simonetta. School subjects didactics in the history of education. Sources and methodology. Italian studies. History of Education and Children's Literature (HECL), IX, 1, 2014, pp. 635-648.

PRUNERI, Fabio. L'istruzione in Sardegna 1720-1848. Bologna: Il Mulino, 2011.

RACCUGLIA, Salvatore. L'insegnamento della lettura. Storia critica dei metodi usati per insegnare a leggere. Palermo: Sandron, 1893.

RAVASIO, Giuseppina. Bell Andrea. In MARTINAZZOLI, Antonio; CREDARO, Luigi. Dizionario illustrato di pedagogia. Vol. I. Milano: Vallardi, pp. 151-153.

RAVASIO, Giuseppina. Lancaster Giuseppe. In MARTINAZZOLI, Antonio; CREDARO, Luigi. Dizionario illustrato di pedagogia. Vol. II. Milano: Vallardi, pp. 410-412. 
RICHMOND, William. Kenneth. Lancaster Joseph. In: LAENG, Mauro (ed.). Enciclopedia pedagogica, vol. IV. Brescia: La Scuola, 1990, p. 6532.

ROGGERO, Marina. Insegnar lettere. Ricerche di storia dell'istruzione in età moderna. Alessandria: Edizioni Dell'Orso, 1992.

ROGGERO, Marina. L'alfabeto conquistato. Apprendere e insegnare nell'Italia tra Sette e Ottocento. Bologna: Il Mulino, 2000.

ROGGERO, Marina. Scuola e riforme nello stato sabaudo. L'istruzione secondaria dalla Ratio studiorum alle Costituzioni del 1772. Torino: Deputazione subalpina di storia patria, 1981.

SANI, Roberto (ed.). Educazione e istituzioni scolastiche nell'Italia moderna (secoli XVXIX). Milano: Pubblicazioni dell'I.S.U Università Cattolica, 1999.

SERRA, Maurizio. Istruzioni di Maurizio Serra al reverendo signor Giannantonio Vargiu maestro della Scuola Normale di Bunnanaro in Sardegna, in seguito al Regio Editto del 24 Giugno 1823. Torino: Stamperia Reale, 1825.

Sistema inglese d'istruzione ossia raccolta de' miglioramenti e delle invenzioni poste in pratica nelle scuole reali d'Inghilterra di G. Lancaster e Piano di educazione pe' fanciulli poveri secondo i metodi combinati del dottor Bell e del predetto sig. Lancaster. Milano: Sonzogno, 1816 [ $1^{\circ}$ ed. 1797$]$.

SOAVE, Francesco. Abbecedario con una raccolta di massime, proverbi e favolette morali e colle tabelle della cognizione delle lettere, del compitare e sillabare e del leggere. Ad uso delle scuole d'Italia. Milano: Presso G. Marelli \& Motta, 1786.

SOAVE, Francesco. Compendio del metodo delle scuole normali per uso delle Scuole d'Italia di Francesco Soave. Bologna: G. Lucchesini, 1805 [1 ${ }^{\circ}$ ed. 1786].

SOAVE, Francesco. Elementi d'aritmetica ad uso delle scuole della Lombardia austriaca di Francesco Soave, vol. I. Milano: Marelli-Motta, 1786; vol. II e Supplemento. Milano: Galeazzi, 1790.

SOAVE, Francesco. Elementi d'aritmetica di Francesco Soave con copiose aggiunte massimamente sul nuovo sistema metrico decimale. Milano: Presso l'agenzia giornalistica Savallo, 1861.

SOAVE, Francesco. Elementi della calligrafia ossia 1'arte di scrivere bene di Francesco Soave. Verona: Stamperia Graziosi a Sant'Apollinare, 1807 [1 ed. 1786].

SOAVE, Francesco. Elementi della pronunzia e dell'ortografia italiana di Francesco Soave C. R. S. ad uso delle scuole del Regno d'Italia. Mantova: presso Giuseppe Braglia, 1808.

SOAVE, Francesco. Grammatica ragionata della lingua italiana di Francesco Soave. Parma: presso i Fratelli Faure librai di S. A. R., 1771.

SOAVE, Francesco. Trattato elementare dei doveri dell'uomo di Francesco Soave C. R. S. ad uso delle scuole d'Italia. Bologna: Tipografia De' Franceschi, 1827. 
SPANO, Giovanni. Cenni sulla vita del teol. Cav. Antonio Manunta di Osilo canonico preb. Nella cattedrale di Cagliari. Cagliari: Tipografia di A. Alagna, 1867.

VIÑAO FRAGO, Antonio. La historia de las disciplinas escolares. Historia de la Educaciçn, 25, 2006, pp. 243-269.

VOLPICELLI, Luigi (ed.). Il pensiero pedagogico della Controriforma. Firenze: GiuntineSansoni, 1960. 